\title{
Comparative anatomical study for fruits of some species of Bunium L. (Umbelliferae) in Iraq
}

\author{
Zainab Abid Aun Ali 1, ${ }^{*}$ Hadeel Radawi H Al- Newani ${ }^{2}$ and Ghussun S Alubaidi ${ }^{1}$ \\ ${ }^{1}$ College of Science for Women- University of Baghdad, Iraq. \\ 2 College of Science- Al Mustansiriyah University, Iraq.
}

GSC Biological and Pharmaceutical Sciences, 2022, 18(01), 107-110

Publication history: Received on 06 December 2021; revised on 12 January 2022; accepted on 14 January 2022

Article DOI: https://doi.org/10.30574/gscbps.2022.18.1.0025

\begin{abstract}
Bunium is one of the interested genus that grow in different region of Iraq, it is within the family Umbelliferae (Apiaceae), and the species within this family have a considerable fruit characteristics. The species that were chosen in this study are: B. brachyactis (Post) H. Wolff, B. caroides (Boiss.) Hausskn. Ex Bornm., B. chaerophylloides (Regel\& Schmalh.) Drude, B. rectangulum Boiss. \& Hausskn., B. verruculosum C.C.Towns. and B. avromanum (Boiss.\& Hausskn) Drude., the study found that the fruits of these species have 5 protrusions different in size but all have the same number of vittae, but some are semiler in size and some are not, the number of vascular element are varied between these species, anatomical characteristics were provided.
\end{abstract}

Keywords: Apiaceae; Bunium; Comparative; Fruits; Iraq; Umbelliferae

\section{Introduction}

Apiaceae in Turkey consist 455 species, 33\% are endemic [1]. Bunium L. is a geophyte genus in Apiaceae family, Apioideae subfamily and (Apieae) tribe distributed in northern hemisphere with approximately 50 species and eight species of theme are in Iraq which their taxonomical history were complicated since the establishment of this genus [2]. The study [3] mentioned that all Bunium spp. are arid or subarid geophytes, they have tuberiform storage roots, primary segmented petiolate, bi or tri- pinnatifid leaves and the calyx without teeth while the petals with inflexed terminal lobes, the fruits are a little bit compressed dorsally or laterally and the fruits contain keel or filiform more or less equal to ribs.

In Iraq the plants grow in the mountains on stony slopes among Quercus scrub, on limestone or on a cultivated hillside, B. brachyactis (Post) H. Wolff, B. caroides (Boiss.) Hausskn. ex Bornm., B. chaerophylloides (Regel \& Schmalh.) Drude, B. avromanum (Boiss. \& Hausskn) Drude. B. rectangulum Boiss. \& Hausskn. and B. verruculosum C.C.Towns, the last one is very rare only a single record exist. [4].

Numerous anatomical studies have been carried out on the members of Bunium grow not in Iraq [5; 6; 7; 2] revealed the differences in the shape of the mericarps in cross-section, rib numbers and development, configuration of the secretory ducts and commissure width is particularly important. The current study interested to examine the anatomy of fruit of 5 species that were available during the time of the study of Bunium grow in Iraq, the study is the first in Iraq

\footnotetext{
* Corresponding author: Zainab Abid Aun Ali

College of Science for Women- University of Baghdad, Iraq.

Copyright (@ 2022 Author(s) retain the copyright of this article. This article is published under the terms of the Creative Commons Attribution Liscense 4.0.
} 


\section{Material and methods}

The study collected fruits of six species of genus Bunium from different location in Iraq during scientific trips in 2009 and 2010. The study followed [8] paraffin method to prepare the cross sections of the fruits then examined the slides by light microscope and clear the anatomical characteristics. The study review the acceptance of the scientific names of the species with the.

\section{Results and discussions}

The acceptance of the binomial scientific name of the genus was confirmed by the world check list organization [9]. The synonyms of the species under study are listed in table (1).

Table 1 The synonyms of the species after World flora on line organization

\begin{tabular}{|l|l|}
\hline \multirow{4}{*}{ B. brachyactis (Post) H. Wolff } & Bunium rhodocephalum Hand- Mazz. \\
\cline { 2 - 2 } B. caroides (Boiss.) Hausskn. Ex Bornm. & Carum brachyactis Post \\
\cline { 2 - 2 } & Cunium elvendia (Boiss.) Drude \\
\cline { 2 - 2 } & Carum elvendia Boiss. \\
\hline \multirow{3}{*}{ B. chaerophylloides (Regel\& Schmalh.) Drude } & Carum chaerophylloides Begelss. \\
\cline { 2 - 2 } & Buniella chaerophylloides (Regel\& Schmalh.) Schischk. \\
\cline { 2 - 2 } & Carum sogdianum Lipsky \\
\cline { 2 - 2 } & Carum tamerlanii Lipsky \\
\hline B. rectangulum Boiss. \& Hausskn. & Carum rectangulum Boiss. \& Hausskn. \\
\hline B. verruculosum C.C.Towns. & No synonym \\
\hline B. avromanum (Boiss. \& Hausskn) Drude. & Carum avromanum Boiss. \& Hausskn. \\
\hline
\end{tabular}

\subsection{Anatomy study: plate 1}

The transvers sections of fruits of Bunium L. are of tow homomorphic mericarps, semi- circular with five protrusions (ribs), the ribs are elongated in B. caroides more than other species. The exocarp in all species covered with thin smooth cuticle and consist of a single row of quadrangular cells enlarged at the top of the ribs; the exocarp is of 1- 2 rows of quadrangular cells become 3- 4 rows of cells at the top of the ribs in B. caroides, but in B. chaerophylloides become 2- 3 rows. The exocarp interrupted near the carpophore.

The mesocarp consist of thin walled paranchyma cells, they are irregular polygonal shaped, the cells enlarged at the top of the ribs.

The vascular bundles are placed at each base of ribs in all species, contain 2- 3 columns of vascular elements in $B$. brachyactis and it contain 3- 4 columns of vascular elements in B. caroides and B. verruculosum while it contain 7- 8 columns of vascular elements in B. rectangulum and B. chaerophylloides, and the vascular bundle of B. avromanum contain 4- 5 columns of vascular elements.

Tow Vallecular vittae and four Commissural vittae, all placed alternate with ribs in all species. The vittae shapes are transvers rectangles with rounded angles, similar in size with lignified walls in $B$. brachyactis, $B$. chaerophylloides, $B$. rectangulum, $B$. verruculosum and $B$. avromanum but the vittae in $B$. caroides are semi-circle in shape.

The endocarp is of one row lamellar collenchyma cells, transvers rectangle, narrow in shape covered the testa. The endosperm located at the center of the section, fill with paranchyma cells, granular contents as much as the study see they are druses crystals. 


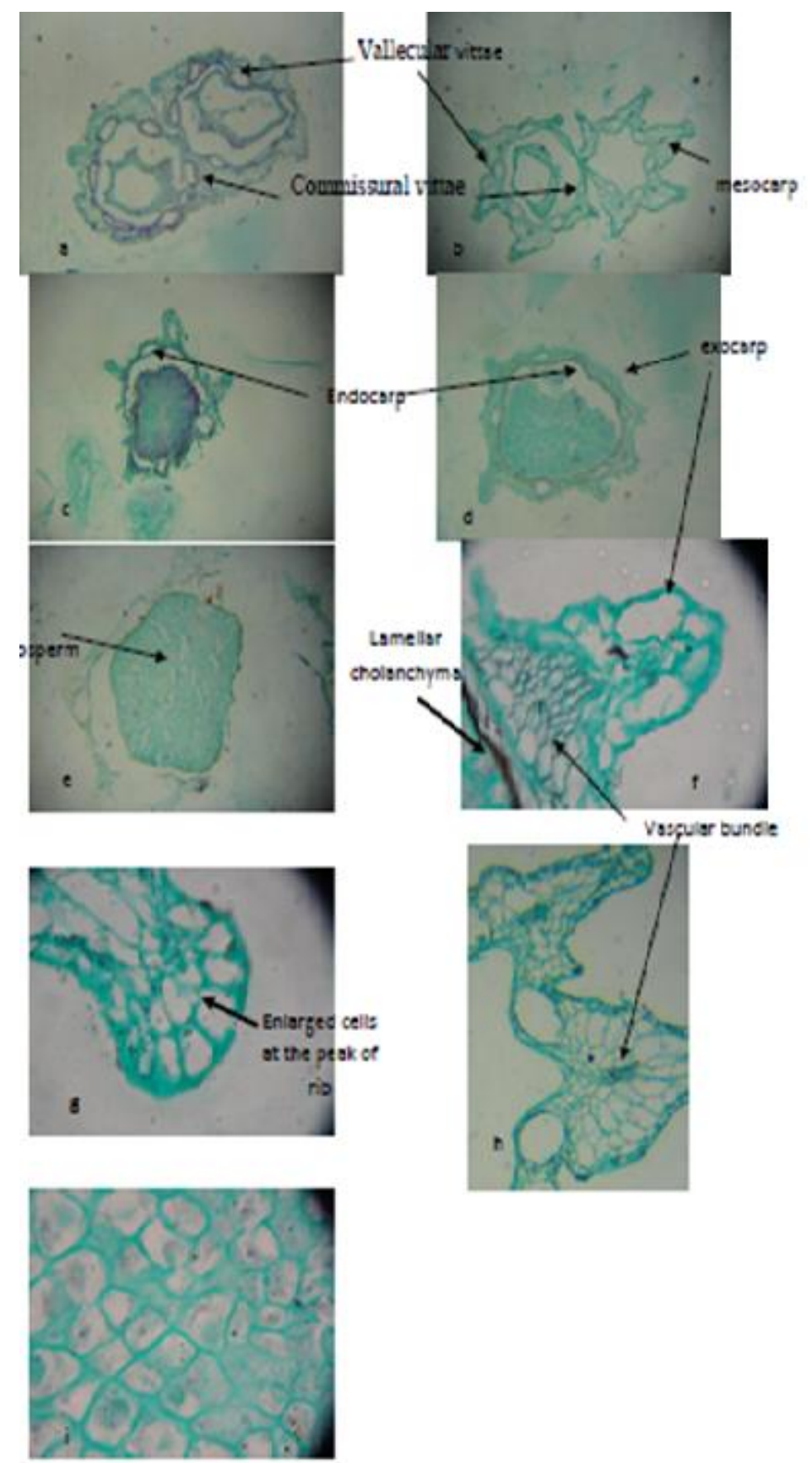

Figure 1 Transvers sections in fruits of some species of Bunium: (a) B. brachyactis. (b) B. caroides. (c) B. chaerophylloides (d) B. rectangulum. (e) B. verruculosum. (f) B. avromanum, vascular bundle at the base of a rib. (g) Enlarged cells at the top of the rib. (i) granulated tissue of endosperm; (a, b, c, d, e) 100x, (f, g, h) 400x, (i) 1000x

\section{Conclusion}

There fruits anatomy of Bunium L. were interested to study; there were variations in the shape of sections due to the shape of fruits, the vascular bundles, some lack collenchyma tissue and this was the first time to study the anatomy of some fruits of Bunium in Iraq.

\section{Compliance with ethical standards}

\section{Acknowledgments}

Acknowledgment is extended to the second author for providing the fruits in this study. 


\section{Disclosure of conflict of interest}

There were no Disclosure of conflict of interest.

\section{References}

[1] Emine Akalin Uruşak, Çağla Kizilarslan. Fruit anatomy of some Ferulago (Apiaceae) species in Turkey. Turkish Journal of Botany. 2013; 37: 434- 445.

[2] Zakharova EA, Degtjareva DG, Kljuykov EV, PM Tilney. The taxonomic affinity of Carum piovanii Chiov. and some Bunium species (Apiaceae). South African Journal of Botany. 2014; 94: 122-128.

[3] GV Degtajareva, EV Kljuykov, TH Samigullin, CM Valiejo- Roman, MG Pimenov. Molecular appraisal of Bunium and some related arid and subarid geophilic Apiaceae- Apioidae taxa of the Ancient Mediterranean. Botanical Journal of Linnean Society. 2009; 160: 149-170.

[4] Shahina A Ghazanfar, John R Edmondson. Flora of Iraq. Ministry of Agriculture Republic of Iraq. 2013; 5(2): 349.

[5] İdman Döm, Karakaya Ma, Ulusoy F, Bani B. Comparative vegetative anatomy of the genera Grammosciadium, Caropodium and Vinogradovia (Apiaceae) in Turkey. Phytotaxa. 2019; 427(1): 009-021.

[6] Degtjareva G, Kljuykov E, Samigullin T, Valiejo-Roman C, Pimenov M. Molecular appraisal of Bunium and some related arid and subarid geophilic Apiaceae-Apioideae taxa of the Ancient Mediterranean. Botanical Journal of the Linnean Society. 2009; 160(2): 149-170.

[7] Amiri H, Dehshiri MM, Alizadeh Bazgir M, Amiri J, Esmaeili A. Essential Oil Composition and Secretory Structures of Bunium Rectangulum Boiss. \& Hausskn. Journal of Plant Environmental Physiology. 2013; 74 (28): 19-26.

[8] Al- Musawi A. A Systematic study of the Genus Hyoscymus (Solanaceae). Ph.D. Thesis, University of Reading. U.K. $1979 ; 291$.

[9] World flora on line organization. www.worldfloraonline.org. 